\title{
Incidence of Pleurisy in Diabetics and Hypertension Patients
}

Hae Rim $\mathrm{Oh}^{1}$, Min Joon Kim ${ }^{1}$, Hee Sang You ${ }^{1,2}$, In Sik Kim ${ }^{1,2}$, Sung Hwa Shin ${ }^{3}$, Eun Jeoung Lee ${ }^{3}$, Sang Sun Kang ${ }^{3}$, and Sunghee Hyun ${ }^{1,2}$

\section{고혈압 환자와 당뇨환자에서 흉막염 발생의 비교}

\author{
오해림 ${ }^{1}$, 김민준 $^{1}$, 유희상 ${ }^{1,2}$, 김인식 $^{1,2}$, 신성화 $^{3}$, 이은정 $^{3}$, 강상순 $^{3}$, 현성희 $^{1,2}$ \\ ${ }^{1}$ 을지대학교 의과대학 임상병리학교실, ${ }^{2}$ 을지대학교 BK21PLUS 시니어헬스케어 대학원, ${ }^{3}$ 충북대학교 사범대학 생물교육학과
}

\begin{abstract}
Pleurisy, an inflammation of the lining around the lungs, is associated with a common complication of several different medical conditions, the most pervasive being viral and mycobacterial infections. We evaluated the relevance of pleurisy and high blood pressure, diabetes. This study is a survey of 136 patients in whom pleural aspiration was performed to confirm the relationship with hypertension or diabetes mellitus and pleurisy. In the 136 patients, $47.8 \%$ were normal people (without hypertension and diabetes mellitus), 32.3\% were hypertension patients, $7.4 \%$ were diabetes mellitus patients, and $12.5 \%$ were patients with hypertension and diabetes mellitus. Odds ratio of normal and hypertension group by pleurisy was 2.524 and the confidence interval was $1.050,6.069$, odds ratio of normal and hypertension group was 4.417 and the confidence interval was 1.101, 17.714. According to these results, hypertension and diabetes mellitus may increase the risk of pleurisy.
\end{abstract}

Keywords: Diabetes mellitus, Hypertension, Pleurisy

This is an Open Access article distributed under the terms of the Creative Commons Attribution Non-Commercial Licens (http://creativecommons.org/licenses/by-nc/4.0) which permits unrestricted non-commercial use, distribution, and reproduction in any medium, provided the original work is properly cited.

Copyright () 2016 The Korean Society for Clinical Laboratory Science. All rights reserved.
Corresponding author: Sunghee Hyun Department of Biomedical Laboratory Science, School of Medicine, Eulji University, 77 Gyeryong-ro 771 beon-gil, Jung-gu, Daejeon 34834, Korea Tel: 82-42-259-1751

Fax: 82-42-259-1759

E-mail: hyunsh@eulji.ac.kr

Received: December 14, 2015 Revised $1^{\text {st. }}$ January 18, 2016 Revised 2 ${ }^{\text {nd }}$ : January 19, 2016 Accepted: January 27, 2016

\section{서 론}

현대인은 경제발전과 더불어 과다한 영양 섭취, 생활도구의 자 동화에 따른 운동 부족과 서구문화의 보편화에 노출되어 왔다. 이 러한 원인으로 고혈압, 당뇨, 비만, 고지혈증 등 성인병의 유병율이 증가하고 있다[1]. 성인병은 그 원인이 불분명하거나, 동시에 여러 가지 질환의 발생, 또는 증상이 뚜렷하지 않고 급변하는 등 까다롭 고 복잡하다. 뿐만 아니라 성인병의 새로운 요인이 현재에도 발견 되고 있으며, 성인병 질환이 나타나는 연령도 점점 낮아지는 추세 이다[2]. 3대 성인병으로는 고혈압(hypertension, HT), 당뇨 (diabetes mellitus, DM)와 동맥경화증(arteriosclerosis)이 알려 져 있다. 이중 당뇨는 5 대 사망 원인 중 하나이며, 고혈압과 동맥경 화증은 심근경색증, 신부전, 뇌졸중 등 합병증을 일으킬 수 있다[3]. 국민건강보험공단이 제공한 통계자료에 따르면 2012년 현재 당뇨 는 10만 명당 5,060명에서 발병하고 있으며 2010년부터 10만 명 당 500 명씩 증가하고 있다. 고혈압은 10 만 명당 13,530 명에서 발 병하고 2010년부터 매년 10만 명당 1,200명씩 증가하고 있다 [4-6].

당뇨환자는 면역기능의 감소로 인해 정상인보다 특정 감염증의 발생빈도가 높게 나타나며[7], 이와 관련된 감염증은 피부, 연조직 
및 골 감염증, 요로감염증, 귀와 코 감염증, 호흡기계 감염증, 소화 기관 감염증 등이 있다. 이 중 호흡기계 감염증에는 폐렴, 결핵, 인 플루엔자 등이 있으며 당뇨병환자에서 폐렴은 $16 \%$, 결핵은 $20 \%$ 의 감염률을 보인다[8]. 또한 일반인보다 당뇨병환자에서 폐렴 발생 률이 1.3 1.8배 높고, 결핵의 감염 위험률은 3 배 높다[9]. 질병관 리본부에서 발행한 결핵환자 신고현황연보에 따르면 2013년 현재 결핵 환자는 10 만 명당 89.6명으로 2001년 이후부터 비슷한 발병 률을 보이고 있다[10]. 고혈압은 40 대 이후 주로 발생하는 혈관의 퇴행성질환으로 알려져 있으며 최근 서구화된 생활습관으로 과체 중, 비만의 증가와 함께 다양한 연령대에서 발병하고 있다. 우리나 라의 경우 40 대 이상의 성인 중 $25 \%$ 가 고혈압에 해당되며 80 세 이 상은 약 $70 \%$ 가 고혈압 환자이다. 고혈압은 심혈관계 질환 이외에 도 당뇨 및 호흡기 질환의 원인이 되기도 한다[11].

따라서 고혈압, 당뇨, 동맥경화증, 결핵의 발병 인구와 노령인구 가 증가함에 따라 감염, 심부전, 악성 종양, 결핵, 외상 등에 의한 흥 수염 증가 원인을 규명해 보고자 하였다. 또한 연관성이 보고된 당 뇨와 결핵 간의 관계에서 더 나아가 결핵이나 폐렴에 의한 흥막염 이 고혈압이나 당뇨와의 연관성을 비교해 보고자 하였다.

\section{대상 및 방법}

\section{1. 연구대상}

본 연구는 충청북도 청주시 소재의 H병원에서 2010년 4월부터 2014년 7월까지 흥수천자를 실시한 입원 환자 164명 중 이미 결핵 이나 폐렴 진단을 받아 치료를 받고 있거나 진단이 불분명한 28명 을 제외한 136 명을 대상으로 하였다. 검사결과의 연구 활용 동의서 를 작성한 총 136명을 고혈압 및 당뇨가 없는 정상인(Normal) 그룹 65 명, 고혈압 $(\mathrm{HT})$ 그룹 44 명, 당뇨( $\mathrm{DM})$ 그룹 10 명, 고혈압과 당뇨 (HT \& DM) 모두 있는 그룹 17 명 등 네 그룹으로 구분하였다.

\section{2. 연구방법}

흥막천자 방법으로 채취한 흉막액 $5 \mathrm{~mL}$ 은 KUBOTA 4000 (Kubota, Tokyo, Japan)을 사용하여 $1000 \mathrm{rpm}$ 으로 10분간 원심 분리하였고, 회수한 상층액 $2 \mathrm{~mL}$ 을 이용하여 생화학적 분석을 시 행하였다.

총단백질(Total Protein, TP)은 TBA-120FR (Toshiba, Tokyo, Japan)를 이용하여 Biuret법으로 측정하였다. Biuret $\left(\mathrm{H}_{2} \mathrm{~N}-\mathrm{C}-\mathrm{N}-\right.$ $\mathrm{NH}_{2}$ )은 알칼리성 $\mathrm{CuSO}_{4}$ 와 반응하여 청자색의 착화합물을 형성한 다. 알부민(albumin)은 TBA-120FR (Toshiba, Tokyo, Japan)을 이용하여 알부민과 결합하여 감소된 색소의 흡광도의 차이를 측정 하여 알부민을 정량하는 Bromcresol Green (BCG)법으로 측정하
였다. 포도당(glucose)은 TBA-120FR (Toshiba, Tokyo, Japan)을 이 용하여 Hexokinase법으로 측정하였다. 포도당은 hexokinase 존 재 시 ATP와 반응하여 G-6-P (glucose-6-phosphate)로 전이되고, 다시 G-6-PDH (glucose-6-phosphate dehydrohenase)와 반응 하여 $\mathrm{NADP}$ 를 $\mathrm{NADPH}$ 로 환원시킨다. 환원된 $\mathrm{NADPH}$ 의 흡광도를 $340 \mathrm{~nm}$ 에서 측정하였다. LDH (Lactate Dehydrogenase)는 TBA-120FR (Toshiba, Tokyo, Japan)을 이용하여 pyruvate to lactate 반응으로 측정하였다. Pyruvate는 $\mathrm{NADH}$ 와 반응하여 lactate와 $\mathrm{NAD}$ 로 반응하고, 남은 pyruvate은 $2,4-\mathrm{DNPH}$ (2,4-Dinitrophenyl Hydrazine)와 반응하여 적갈색을 나타낸다. ADA (Adenosine deaminase)는 HITACHI 7600 (Hitachi, Tokyo, Japan)을 이용하여 효소법으로 측정하였다. $\mathrm{ADA}$ 는 purine 대사 경로에 관여하는 효소로 purine nucleoside의 adenosine, deoxyadenosine을 탈아미노하여 각각 minosine, deoxyminosine을 생성하는 반응을 촉매한다.

\section{3. 통계분석}

본 연구의 자료는 Windows SPSS Program Ver. 22.0 (IBM, Armonk, USA)을 이용하여 항목별로 평균값과 표준편차를 분석하 였다. 정상 그룹, 고혈압 그룹, 당뇨 그룹, 고혈압과 당뇨 모두 갖는 그룹의 평균치 분석은 $\mathrm{ANOVA}$ 를 사용 하였다. 로지스틱 회귀분석 을 사용하여 당뇨병, 고혈압의 유병유무를 독립변수로 흥막염, 결 핵, 폐렴 유무 등을 종속변수로 하여 오즈비를 이용하여 비교 분석 하였다. 유의수준은 $p<0.05$ 로 설정하였다.

\section{결 과}

\section{1. 연구대상자의 임상적 특성}

흥수천자를 시행한 136 명의 연구대상자를 고혈압과 당뇨가 없 는 정상인 그룹, 고혈압 그룹, 당뇨 그룹, 고혈압과 당뇨를 모두 갖 는 그룹 등 네 그룹으로 구분하여 나이와 성별을 비교하였다. 정상 인 그룹은 65 명(47.8\%)으로 평균연령은 $57.2 \pm 22.3$ 세였고, 고혈 압 그룹은 44 명(32.3\%)으로 평균연령은 77.2 \pm 9.2 세, 당뇨 그룹은 10 명 $(7.4 \%)$ 으로 $62.2 \pm 14.0$ 세, 고혈압과 당뇨를 모두 갖는 그룹은 17 명(12.5\%)으로 $67.5 \pm 14.4$ 세였다. 네 그룹 중에서 정상인 그룹 의 평균 나이가 제일 낮았으며, 고혈압 그룹에서 제일 높았다. 성별 은 정상인 그룹이 남녀 각각 47 명과 18 명이었고, 고혈압 그룹은 남 녀 모두 각각 22명씩이었다. 당뇨 그룹은 남녀 각각 6명과 4명이었 으며 고혈압과 당뇨를 모두 갖는 그룹에서는 남녀 각각 13 명과 4 명 이었다. 다른 세 그룹에서는 남성이 여성보다 많았으나 고혈압 그 룹에서는 남녀 수가 일치하였다(Table 1). 


\section{2. 생화학적 검사 결과}

정상인 그룹, 고혈압 그룹, 당뇨 그룹, 고혈압과 당뇨를 모두 갖 는 그룹 등 네 그룹으로 구분하여 총단백질, 알부민, 포도당, $\mathrm{LDH}$ 와 $\mathrm{ADA}$ 의 생화학 검사를 시행하였다. 각 항목별 수치는 평균ㅍㅍㅍ 준편차로 나타냈으며 정상인 그룹 65 명, 고혈압 그룹 44 명, 당뇨 그 룹 10 명, 고혈압과 당뇨를 모두 갖는 그룹 17 명 중에서 검사를 시행 하지 않은 건수는 포함하지 않았다(Table 2).

각 그룹에서 시행한 생화학적 검사결과는 ANOVA로 분석하였 다. 분산분석결과 포도당은 $p$ 값이 0.000 으로 그룹 간에 통계적으 로 유의한 차이가 있었다. 총단백질, 알부민, $\mathrm{ADA}$ 는 $p$ 값이 각각 $0.173,0.119,0.060$ 으로 분산분석에서는 유의한 차이가 없었으 나 다중비교에서 그룹 간에 차이를 보였다. 그러나 $\mathrm{LDH}$ 는 $p$ 값이 0.526 으로 그룹 간의 차이가 없었다(Table 2). 분산분석에서 각 그 룹간의 다중비교 결과는 다음과 같다. 총단백질은 $p$ 값이 각각 정상 인과 고혈압 간 0.406 , 정상인과 당뇨 간 0.030 , 정상인과 고혈압 및 당뇨 간 0.887 , 고혈압과 당뇨 간 0.099 , 고혈압과 고혈압 및 당 뇨 간 0.663 , 당뇨와 고혈압 및 당뇨 간 0.078 로 정상인 그룹과 당뇨 그룹 간 비교에서 유의한 차이를 보였다. 알부민의 $p$ 값은 각각 $0.077,0.043,0.545,0.346,0.538,0.204$ 로 총단백질과 마찬가 지로 정상인 그룹과 당뇨 그룹 간 비교에서 유의한 차이를 보였다. 포도당은 정상인 그룹과 당뇨 그룹, 정상인 그룹과 고혈압과 당뇨 모두 갖는 그룹, 고혈압 그룹과 당뇨 그룹, 고혈압 그룹과 고혈압과 당뇨 모두 갖는 그룹에서 모두 $p=0.000$ 으로 유의한 차이를 보였다. 그러나 정상인 그룹과 고혈압 그룹 간에는 $p=0.139$, 당뇨 그룹과 고혈압 및 당뇨 그룹 간에는 $p=0.249$ 로 유의하지 않았다. 당뇨환자
에서는 당뇨조절 약물 복용 전 측정치로 포도당의 농도 값이 높게 검출되었다. $\mathrm{ADA}$ 의 경우 정상인 그룹과 고혈압 그룹 간 비교에서 $p=0.009$ 로 유의한 차이를 보였다.

\section{3. 흉막염과 고혈압 및 당뇨와의 관계}

폐렴, 결핵, 악성종양 등을 포함하는 흥막염으로 진단된 정상인 그룹과 고혈압 그룹 간의 오즈비는 2.524 이며 이의 $95 \%$ 신뢰구간 은(1.050, 6.069)로 1 을 포함하고 있지 않으므로 고혈압이 흥막염 의 위험률을 높인다고 볼 수 있다. 정상인 그룹과 당뇨 그룹 간의 오 즈비는 4.417이며 95\% 신뢰구간은 $(1.101,17.714)$ 로 1을 포함하 지 않으므로 당뇨가 흥막염의 위험률을 높인다고 할 수 있다. 또한 흥막염 중에서 결핵으로 진단된 정상인 그룹과 고혈압 그룹 간 오 즈비는 6.4 로 이의 $95 \%$ 신뢰구간은 $(1.889,21.680)$ 으로 1을 포함 하지 않으므로 고혈압이 결핵 위험률을 높인다고 할 수 있다. 그러 나 결핵인 정상인과 당뇨환자에서는 오즈비가 $1.714,95 \%$ 신뢰구 간이(0.471, 6.240)으로 1을 포함하므로 정상인과 당뇨환자에서 결핵 위험률은 차이가 없었다. 흥막염 중에서 폐렴으로 진단된 정 상인과 고혈압환자에서는 오즈비가 0.444 이고, $95 \%$ 신뢰구간은 $(0.114,1.726)$ 으로 1 을 포함하므로 정상인과 고혈압환자에서 폐 렴 위험률은 차이가 없었다. 연구 대상자 중에서 당뇨환자에서는 폐렴 환자가 없어 폐렴인 정상인과의 오즈비를 구할 수 없었다 (Table 3).

\section{고 찰}

폐렴의 발생률은 일반인보다 당뇨환자에서 $1.3 \sim 1.8$ 배 높고, 결

Table 1. Numbers of normal people and adult disease patients

\begin{tabular}{ccccc}
\hline & Normal $(\mathrm{n}=65,47.8 \%)$ & $H T(n=44,32.3 \%)$ & $\mathrm{DM}(\mathrm{n}=10,7.4 \%)$ & $H T \& D M(n=17,12.5 \%)$ \\
\hline Age & $57.2 \pm 22.3$ & $77.2 \pm 9.2$ & $62.2 \pm 14.0$ & $67.5 \pm 14.4$ \\
$\operatorname{Sex}(M / F)$ & $47 / 18$ & $22 / 22$ & $6 / 4$ & $13 / 4$ \\
\hline
\end{tabular}

Mean \pm SD.

Abbreviation: HT, hypertension; DM, diabetes mellitus; M, male; F, female.

Table 2. Biochemical test results of normal people and adult disease patients

\begin{tabular}{lrrrrr}
\hline & \multicolumn{1}{c}{ Normal } & \multicolumn{1}{c}{ HT } & \multicolumn{1}{c}{ DM } & HT \& DM & $p$-value \\
\hline Total protein $(\mathrm{g} / \mathrm{dL})$ & $4.1 \pm 1.5(\mathrm{n}=65)$ & $3.8 \pm 1.3(\mathrm{n}=43)$ & $3.0 \pm 1.5(\mathrm{n}=10)$ & $4.0 \pm 1.6(\mathrm{n}=17)$ & 0.173 \\
Albumin $(\mathrm{g} / \mathrm{dL})$ & $2.3 \pm 1.0(\mathrm{n}=62)$ & $2.0 \pm 0.8(\mathrm{n}=40)$ & $1.7 \pm 0.9(\mathrm{n}=10)$ & $2.1 \pm 0.8(\mathrm{n}=15)$ & 0.119 \\
Glucose $(\mathrm{mg} / \mathrm{L})$ & $104.1 \pm 36.0(\mathrm{n}=61)$ & $118.2 \pm 28.7(\mathrm{n}=39)$ & $193.1 \pm 70.9(\mathrm{n}=10)$ & $171.6 \pm 83.9(\mathrm{n}=16)$ & $0.000^{\star}$ \\
LDH (IU/L) & $958.6 \pm 765.4(\mathrm{n}=56)$ & $644.6 \pm 634.4(\mathrm{n}=37)$ & $414.1 \pm 402.1(\mathrm{n}=8)$ & $369.5 \pm 223.4(\mathrm{n}=13)$ & 0.526 \\
ADA (IU/L) & $49.3 \pm 36.3(\mathrm{n}=59)$ & $31.0 \pm 33.8(\mathrm{n}=39)$ & $36.2 \pm 33.2(\mathrm{n}=9)$ & $36.5 \pm 25.7(\mathrm{n}=17)$ & 0.060 \\
\hline
\end{tabular}

Mean \pm SD.

${ }^{*} p<0.05$

Abbreviation: HT, hypertension; DM, diabetes mellitus; LDH, Lactate Dehydrogenase; ADA, Adenosine deaminase. 
Table 3. Relations with pleurisy and hypertension, diabetes mellitus patients

\begin{tabular}{lllcc}
\hline & & \multirow{2}{*}{$\begin{array}{l}\text { Odds } \\
\text { Ratio }\end{array}$} & \multicolumn{2}{c}{ 95\% Confidence Interval } \\
\cline { 5 - 5 } Pleurisy & & & Lower & Upper \\
\hline \multirow{4}{*}{ Tuberculosis } & $\mathrm{N}-\mathrm{HT}$ & 2.524 & 1.050 & 6.069 \\
& $\mathrm{~N}-\mathrm{DM}$ & 4.417 & 1.101 & 17.714 \\
& $\mathrm{~N}-\mathrm{HT}$ & 6.4 & 1.889 & 21.680 \\
Pneumonia & $\mathrm{N}-\mathrm{DM}$ & 1.714 & 0.471 & 6.240 \\
& $\mathrm{~N}-\mathrm{HT}$ & 0.444 & 0.114 & 1.726 \\
& $\mathrm{~N}-\mathrm{DM}$ & - & - & - \\
\hline
\end{tabular}

Abbreviation: N, normal; HT, hypertension; DM, diabetes mellitus.

핵에 감염될 위험률은 당뇨환자에서 3 배 높은 것으로 보고되어 있 다[9]. 이와 같이 당뇨는 결핵 발병률을 높이는 위험인자 중 하나로 알려져 있으며, 비당뇨병 고혈압 환자보다 당뇨 환자에서 결핵 발 생률이 높게 나타난다[12]. 연관성이 밝혀진 당뇨와 결핵 간의 관계 를 토대로 결핵이나 폐렴에 의한 흥막염이 고혈압, 당뇨와 연관성 이 있는지 알아보고자 하였고, 흥막염에 의한 흥수의 생화학적 검 사에서도 고혈압이나 당뇨와 관련성이 있는지 알아보고자 하였다.

연구대상자 136명 중에서 고혈압이나 당뇨가 없는 정상인은 $47.8 \%$, 고혈압이나 당뇨 둘 중 하나라도 있는 사람은 $52.2 \%$ 로 나타 났으며, 고혈압 그룹이나 당뇨 그룹은 현재 혈압 조절 약물이나 당 뇨 조절 약물을 복용 중이다. 그러나 당뇨환자에서는 약물 복용 전 측정치로 포도당의 농도가 높게 측정되었다(Table 2). 정상인을 제 외한 연구대상자 중 고혈압은 $32.3 \%$, 당뇨는 $7.4 \%$, 고혈압 및 당뇨 는 $12.5 \%$ 로 고혈압인 사람이 당뇨인 사람보다 4.4 배 많았다. 이것 은 국민건강보험공단에서 제공한 통계자료에서 2012년 현재 고혈 압 발생은 10 만 명당 13,530 명, 당뇨 발생은 10 만 명당 5,060 명으 로 고혈압 발생률이 당뇨 발생률의 2.6배와 같은 양상을 보였다 $[13,14]$.

결핵균 감염으로 발생하며 침범하는 부위에 따라 폐결핵, 장결 핵, 흥막결핵 등으로 구분 할 수 있으며, 흥막결핵은 흥막염을 유발 하게 된다. 흉막은 흥강을 둘러싸고 있는 얇은 막으로 그 내부에는 흥수가 소량 존재하여 호흡운동 시 윤활유의 역할을 한다. 그러나 결핵, 폐렴과 같은 폐질환이나 흥막 자체의 병변에 의해 삼출액을 동반한 흥수가 증가될 수 있으며, 심장, 간, 신장의 이상으로 인한 이차적 증상으로 여출액을 동반한 흉수가 증가될 수 있다[15,16]. 이러한 흥수 증가의 원인을 알아내기 위해 흥수천자를 시행하여 생 화학적 검사, 세균배양검사, 세포검사 등을 실시하게 된다 [14,17,18]. 특히 생화학적 검사에서 총단백질, 포도당, $\mathrm{LDH}$, $\mathrm{ADA}, \mathrm{CEA}$ (Carcinoembryonic Antigen) 등의 수치와 혈청과의 비율을 통해 흉막염을 삼출액과 여출액으로 감별하고 있다 $[13,16]$.
1972년 Light's criteria에 의한 흉막염의 삼출액과 여출액 감별 이 현재 오류가 많음이 밝혀져 흥막액과 혈청에서의 총단백질 또는 알부민의 구배율 등이 사용되고 있다[18]. 당뇨일 때 총단백질에서 주로 알부민의 부족으로 혈청에서 저단백이 나타날 수 있으며, 정 상인 그룹과 당뇨 그룹 비교에서 총단백질과 알부민이 각각 $p=0.030, p=0.043$ 으로 혈청에서와 같이 유의한 차이를 보이며 낮 게 나타났다. 포도당은 당뇨일 때 혈청에서 높게 나타나는데 흥수 에서도 당뇨 그룹과 다른 그룹과의 비교에서 모두 $p=0.000$ 으로 유 의하게 높은 것으로 나타났다. $\mathrm{LDH}$ 는 염증 정도를 나타내는데 그 룹간 비교에서 유의한 차이를 보이는 그룹은 없었다. 그러나 LDH 측정치가 정상인 그룹은 최소값 99 , 최대값 3013 이었으며, 고혈압 그룹은 최소값 113 , 최대값 2,299 였고, 당뇨 그룹은 최소값 101 , 최대값 1,183 이었으며, 고혈압 및 당뇨 그룹은 최소값 143 , 최대값 711로 넓은 분포를 보였다. $\mathrm{LDH}$ 는 심근경색, 심부전, 폐경색 등과 같은 심폐질환, 악성빈혈, 백혈병과 같은 혈액질환, 급성 간염이나 간경변과 같은 간질환 또는 악성종양이 있을 경우 증가하는 효소이 다[12]. 정상인 그룹, 고혈압 그룹, 당뇨 그룹, 고혈압과 당뇨 모두 갖는 그룹 중에서 심장질환이나 간질환이 있는 사람이 각각 5 명, 3 명, 2 명, 3 명이었고, 악성종양이 있는 사람이 각각 5명, 8 명, 0 명, 2 명이었다. 이러한 변수가 $\mathrm{LDH}$ 값에 큰 영향을 준 것으로 사료된다. 흥막염의 원인 중에서 당뇨와 관련이 있는 결핵에 의한 흥막염이 $60 \sim 70 \%$ 로 가장 높은 빈도를 보이는데 $\mathrm{ADA}$ 활성 정도를 결핵성 흥막염과 비결핵성 흥막염의 감별진단으로 이용하고 있다[16]. 즉, $\mathrm{ADA}$ 수치가 $70 \mathrm{IU} / \mathrm{L}$ 이상이면 결핵성 흥수일 가능성이 높다[14]. 네 그룹 모두 평균 $\mathrm{ADA}$ 수치가 $70 \mathrm{IU} / \mathrm{L}$ 를 넘지는 않았으나 정상 그 룹과 고혈압 그룹 간에 $p=0.009$ 으로 유의한 차이를 보였다.

정상인 그룹과 고혈압 그룹 간의 오즈비는 $95 \%$ 신뢰구간 (1.050, 6.069), 정상인 그룹과 당뇨 그룹 간의 오즈비는 $95 \%$ 신뢰 구간(1.101, 17.714)로 모두 신뢰구간이 1을 포함하지 않아 고혈 압과 당뇨가 흥막염의 위험률을 증가시킨다고 할 수 있다. 또한 흥 막염을 결핵, 폐렴으로 세분화하여 각각 정상인 그룹과 고혈압 그 룹, 정상인 그룹과 당뇨 그룹의 오즈비를 분석하였다. 그 결과 결핵 인 정상인과 고혈압 그룹 간에 $95 \%$ 신뢰구간은 $(1.889,21.680)$ 으 로 1을 포함하지 않으므로 고혈압이 결핵 위험률을 높인다고 할 수 있다. 그러나 결핵인 정상인과 당뇨환자, 폐렴인 정상인과 고혈압 환자에서는 95\% 신뢰구간이 각각(0.471, 6.240), (0.114, 1.726) 으로 1 을 포함하므로 정상인과 당뇨환자에서의 결핵 위험률과 정 상인과 고혈압환자에서의 폐렴 위험률은 차이가 없었다. 연구 대상 자 중에서 당뇨환자에서는 폐렴 환자가 없어 폐렴인 정상인과의 오 즈비는 구할 수 없었다. 일반인보다 당뇨병환자에서 폐렴 발생률이 $1.3 \sim 1.8$ 배 높고, 결핵에 걸릴 위험률은 3 배 높은 등 연관성이 밝혀 
진 당뇨와 결핵 간의 오즈비가 신뢰구간이 1 을 포함하였으며 이것 은 흉막염의 종류를 세분화함으로 인해 대상자 수가 적어 발생한 결과라고 사료된다[3].

이 논문의 한계점으로는 첫째, 고혈압이나 당뇨에서 흥막염의 위험률이 증가한다는 결론이 나왔으나, 연구대상자의 수가 적어 흥 막염 종류에 따른 비교가 정확히 이루어지지 못했다. 본 연구는 이 차병원 입원환자를 대상으로 진행되어 일반인을 대조군으로 사용 하지 못한 것이 제한점으로 작용할 수 있다. 그러나 다른 연구에서 폐동맥 색전증, 당뇨병, 고혈압, 급성 충수돌기염 환자를 대조군으 로 사용한 예가 있다[19]. 둘째, 본 연구 대상자는 고혈압이나 당뇨 약을 복용하는 중으로, 약제의 복용 전후 그룹과의 비교가 이루어 지지 않아 약제가 미칠 수 있는 영향을 고려하지 못했다. 그러므로 이에 대한 연구가 포함된다면 좀 더 정확한 결과를 얻을 수 있을 것 으로 기대된다. 연구결과를 종합하면 흥막염이 없는 고혈압환자와 당뇨환자에서 흥막염 발병과 관련된 주의 깊은 관찰이 필요하다고 사료된다.

\section{요 약}

흥막염은 폐를 둘러싸는 흥막에서의 염증이다. 흉막염은 바이러 스 감염과 결핵균 감염을 포함하는 다양한 원인으로 발병한다. 본 연구에서는 흥수천자를 실시한 입원환자 136 명을 대상으로 흥막 염과 고혈압, 당뇨와의 관계를 알아보고자 한다. 연구대상자 136 명 중에서 고혈압이나 당뇨가 없는 정상인은 $47.8 \%$, 고혈압 $32.3 \%$, 당뇨 $7.4 \%$, 고혈압 및 당뇨 $12.5 \%$ 의 분포를 보였다. 흥막염 유무에 따른 정상인 그룹과 고혈압 그룹 간의 오즈비는 2.524이며 이의 $95 \%$ 신뢰구간은(1.050, 6.069)로 1을 포함하고 있지 않으므 로 고혈압이 흥막염의 위험률을 높인다고 볼 수 있다. 또한, 정상인 그룹과 당뇨 그룹 간의 오즈비는 4.417이며 95\% 신뢰구간은 (1.101, 17.714)로 1을 포함하지 않으므로 당뇨가 흥막염의 위험 률을 높인다고 할 수 있다. 이상의 결과에 따라 고혈압과 당뇨질환 은 흉막염의 발병과 관련성이 있다.

\section{Acknowledgements: None}

Funding: None

Conflict of interest: None

\section{References}

1. Koo JW. Adult disease and exercise. Industrial Health. 2006; 214:47-50.

2. Barker DP. The developmental origins of chronic adult disease.
Acta Pædiatr. 2004;446(Suppl):26-33.

3. de Boo Ha, Harding JE. The developmental origins of adult disease (Barker) hypothesis. Aust N Z J Obstet Gynaecol. 2006; 46:4-14.

4. Choi KM, Park HS, Han JH, Lee JS, Lee J, Ryu OH, et al. Prevalence of prehypertension and hypertension in a Korean population: Korean national health and nutrition survey 2001.J Hypertension. 2006;24(8):1515-1521.

5. Chang SM, Yoon YO. Study on biochemical results as risk factors of hypertension in rural and semirural communities. Korean J Clin Lab Sci. 1984;15(1):65-68

6. National Health Insurance portal. 2014 Health Index [Internet]. Seoul: National Health Insurance; 2013 [cited 2014 March]. Available from:http://sis.nhis.or.kr/site/sis/ggog023m01/. last visited on 2014 Oct 13.

7. Bertoni AG, Saydah S, Brancati FL. Diabetes and the risk of infection related mortality in the U.S. Diabetes Care. 2001; 24:1044-1049.

8. Muller LM, Gorter KJ, Hak E, Goudzwaard WL, Schellevis FG, Hoepelman AIM, et al. Increased risk of common infections in patients with type 1 and type 2 diabetes mellitus. Clin Infect Dis. 2005; 41(3):281-288.

9. Christie YJ, Megan BM. Diabetes mellitus increases the risk of active tuberculosis: A systematic review of 13 observational studies. PLOS Medicine. 2008;5(7):1091-1101.

10. Korea Centers for Disease Control and Prevention. Annual report on the notified tuberculosis in Korea. In: Public health weekly report. Korea Centers for Disease Control and Prevention. 2013;10-12.

11. Jin BH, Kim JY, Jeon MJ, Kim HJ, Kim JH. Relation of serum lipid concentrations and body mass index between hypertensive patients and normotensive subjects. Korean J Clin Lab Sci. 1995; 27:141-151.

12. Park EK, Bae JH, Jung YM, Chung SH, Lee JH, Kim SH, et al. Incidence of tuberculosis in Korean diabetics: Comparison with that in non-diabetic hypertensive subjects. Kor J Int Med. 2010; 79(6):646-654.

13. Kim HK, Jo WM, Ryu SM, Choi YH, Shim JH, Sohn YS, et al. Significance of vascular endothelial growth factor in pleural effusion. Kor J Thoracic and Cardiovascular Surgery. 2004; 7(9):781-786.

14. Cho H, Kim HI, Eum MS, Kwon HJ, Oh YL, Kim KS, et al. Pleural fluid to serum cholinesterase ratio for the differential diagnosis of transudates and exudates. Tuberculosis and Respiratory Disease. 2000;48(5):781-787.

15. Korea Centers for Disease Control and Prevention. 2014 Disease web statistics system [Internet]. Sejong: Korea Centers for Disease Control and Prevention, National health information portal, Pleurisy and empyema. 2013 [cited 2014 March]. Available from: http://health.mw.go.kr/ ealthInfoArea/ ealthInfo/View.do?idx=1810, last visited on 2014 Oct 18.

16. Jeon CY and Murray MB. Diabetes mellitus increases the risk of active tuberculosis: A systematic review of 13 observational studies. PLOS Medicine. 2008;5(7):1091-1101.

17. Ryu JS, Yong SJ, Song KS, Shin KC, Lee WS, Kang SG, et al. The usefulness in an automated kinetic method in determining of ADA activity in pleural fluid. Tuberculosis and Respiratory 
Disease. 1995;42(6):838-845.

18. Lee JH, Jang SH, Lee HL, Kwak SM, Chang JH, Kim BI, et al. Clinical significance of the combined assay of pleural fluid ADA activity and CEA level in the various pleural effusions.
Tuberculosis and Respiratory Disease. 1993;40(1):35-42.

19. Pablos-Mendez A, Blustein J, Knirsch CA. The role diabetes mellitus in the higher prevalence of tuberculosis among Hispanics. Am J Public Health. 1997;87:574-579. 